\title{
34. YTTRIUM AND OTHER TRACE ELEMENTS IN BASALTS FROM DSDP LEG 37
}

\author{
R. St J. Lambert, Department of Geology, University of Alberta, Edmonton, Alberta, Canada \\ and \\ J.G. Holland, Department of Geological Sciences, University of Durham, South Road, Durham, England
}

\section{INTRODUCTION}

This report is based on major and trace $(\mathrm{Ba}, \mathrm{Nb}, \mathrm{Zr}$, $\mathrm{Y}, \mathrm{Sr}, \mathrm{Rb}, \mathrm{Zn}, \mathrm{Cu}, \mathrm{Co}, \mathrm{Ni})$ element analyses by XRF for 20 basalts from Hole 332A, 25 from Hole 332B, 2 from Hole 333A, 2 basalts and 2 peridotites from Site 334 , and 4 basalts from Site 335. In addition, information was available from thin sections of 27 samples (those for which Co data are not given) and from $\mathrm{Sr}$ and $\mathrm{O}$ isotopes and $\mathrm{Th}$ and $\mathrm{U}$ abundances (Gray et al., this volume). Data are presented in Chapters 2, 3, 4, and 5 (this volume).

\section{CLASSIFICATION BY TRACE ELEMENTS}

Facets of the geochemistry have been extracted from the tabulated data and are presented in Figures 1-10. Like most basalt suites, Leg 37 basalts possess a high positive correlation of $\mathrm{Ti}$ and $\mathrm{Zr}$, which can be extended to include $\mathrm{Nb}, \mathrm{Y}, \mathrm{Rb}, \mathrm{Zn}, \mathrm{P}_{2} \mathrm{O}_{5}, \mathrm{Na}_{2} \mathrm{O}, \mathrm{Fe}_{2} \mathrm{O}_{3} / \mathrm{MgO}$, and $\mathrm{U}$, all of which correlate positively.

The basalts from Leg 37 can therefore be classed as follows: (1) High $\mathrm{Zr}$ basalts from Holes $332 \mathrm{~A}$ and $332 \mathrm{~B}$ ( $\mathrm{Zr} \geq 50 \mathrm{ppm}$ ); (2) Low $\mathrm{Zr}$ basalts from Holes $332 \mathrm{~A}$ and 332B; and (3) Basalts from Sites 334 and 335 which have high $\mathrm{Y}$ relative to $\mathrm{Zr}$ compared with Holes $332 \mathrm{~A}$ and $\mathrm{B}$ (Figure 1).

The two samples of basalt from Hole 333A fall into the first two categories listed above, but do not show a positive $\mathrm{Fe}_{2} \mathrm{O}_{3} / \mathrm{MgO}$ versus $\mathrm{Zr}$ correlation (Figure 2).

The $\mathrm{Zr}$-Y correlation is shown in Figure 1, where it can be seen that all samples analyzed fall into a simple pattern, except 332B-23-1, 78-80 cm (6A), from Unit 5 of the shipboard classification. In the high $\mathrm{Zr}$ group, Hole $332 \mathrm{~A}$ has slightly higher $\mathrm{Y}$ for a given $\mathrm{Zr}$ than Hole 332B. Because it is currently widely assumed that $\mathrm{Ti}, \mathrm{Zr}$, and $\mathrm{Y}$ are alteration-resistant (Cann, 1970), it was provisionally assumed that a classification based on their abundances could be genetically significant. A good $\mathrm{Zr}$ and $\mathrm{Fe}_{2} \mathrm{O}_{3} / \mathrm{MgO}$ correlation is shown on Figure 2, where the same groups appear as in Figure 1. The only highly aberrant sample is $332 \mathrm{~A}-7-1,40-43 \mathrm{~cm}$ (\#5), which has unusually low $\mathrm{MgO}$. A similar pattern is observable in basalts from Iceland (Sigvaldason, 1974), but all of Sigvaldason's basalts have $\mathrm{Zr}>50$ ppm.

$\mathrm{Ti}$ and $\mathrm{Na}$ show the same sort of pattern (Figure 3) except that in the Hole $332 \mathrm{~B}$ high $\mathrm{Zr}$ group there is no variation of $\mathrm{Ti}$ with $\mathrm{Na}$. $\mathrm{Ti}$ and $\mathrm{Na}$ were therefore compared with $\mathrm{Nb}, \mathrm{Zr}, \mathrm{Y}$, and $\mathrm{Rb}$ (halving $\mathrm{Zr}$ to arbitrarily reduce its significance) on Figure 4 , where the same pattern is seen, the two aberrant samples being from Units 2 and 5 of Hole 332B.
The close interrelationship of the elements given in Figures 1-4 suggests that either alteration processes have been very uniform or that there is some systematic genetic control of the observed variations. High and variable plagioclase contents, primary or accumulative, could produce some of the observed variation, but not the correlation of $\mathrm{Fe}_{2} \mathrm{O}_{3} / \mathrm{MgO}$ with the other elements. A more satisfactory choice for overall cause is variation of degree of partial melting and fractional crystallization, because high degrees of melting and low degrees of fractional crystallization would presumably change major/trace element ratios in broadly the manner observed in this suite.

\section{YTTRIUM GEOCHEMISTRY}

Variation of $\mathrm{Y}$ with $\mathrm{CaO}, \mathrm{Nb}$, and $\mathrm{Zn}$ is shown in Figures 5-7. The high and low $\mathrm{Zr}$ groups are readily identified in each figure, and attention is drawn to the correlation with $\mathrm{Zn}$, an element normally geochemically associated with ferromagnesian minerals, roughly equally in pyroxenes and olivines, but probably more highly concentrated in magnetite.

Variation of $\mathrm{Y}$ with $\mathrm{CaO}$ was shown to be of some interest in differentiated igneous series by Lambert and Holland (1974). The data from DSDP Leg 37 shown in Figure 5 suggest that ocean-floor basalts are not necessarily relatively rich in Y (Lambert and Holland, 1974 , p. 1404), but that circumstances do exist in basalt generation which will produce high Y (e.g., in Site 335, Figure 5). The Leg 37 samples fall into two main groups, the low- $\mathrm{Zr}$ set of Holes $332 \mathrm{~A}$ and $332 \mathrm{~B}$, which show scatter between $\mathrm{Y}$ and $\mathrm{CaO}$, and the high- $\mathrm{Zr}$ set and samples from 333A, 334, and 335, which together appear to show a "trend" of increasing $Y$ with decreasing $\mathrm{CaO}$. This feature is also clearly exhibited by Icelandic basalts, as shown in Figure 5, Sigvaldason's (1974) samples lying between the boundaries indicated. His subsets 1-3 can also be distinguished by their $\mathrm{CaO} / \mathrm{Y}$ ratios.

The high-Zr set data can be caused in either or both of two ways: systematic mechanical mixture of constant $\mathrm{CaO}, \mathrm{Y}$ minerals (e.g., An75 + a constant ratio of pyroxene and olivine) or fractionation of a mineral or minerals lying along the trend, such as $\mathrm{An}_{75}$ or $\mathrm{Ca}$-poor pyropic garnets (see Lambert and Holland, 1974, fig. 1). Generation of this pattern by secondary alteration seems ruled out by the similar behavior of Icelandic and Leg 37 rocks.

The low- $\mathrm{Zr}$ set $\mathrm{CaO}-\mathrm{Y}$ data are less easy to interpret. The high $\mathrm{CaO}$ samples may contain $\mathrm{CaCO}_{3}$, but in the absence of $\mathrm{CO}_{2}$ data no conclusion is possible. The samples with low $\mathrm{CaO}$ and low $\mathrm{Y}$ all have low 


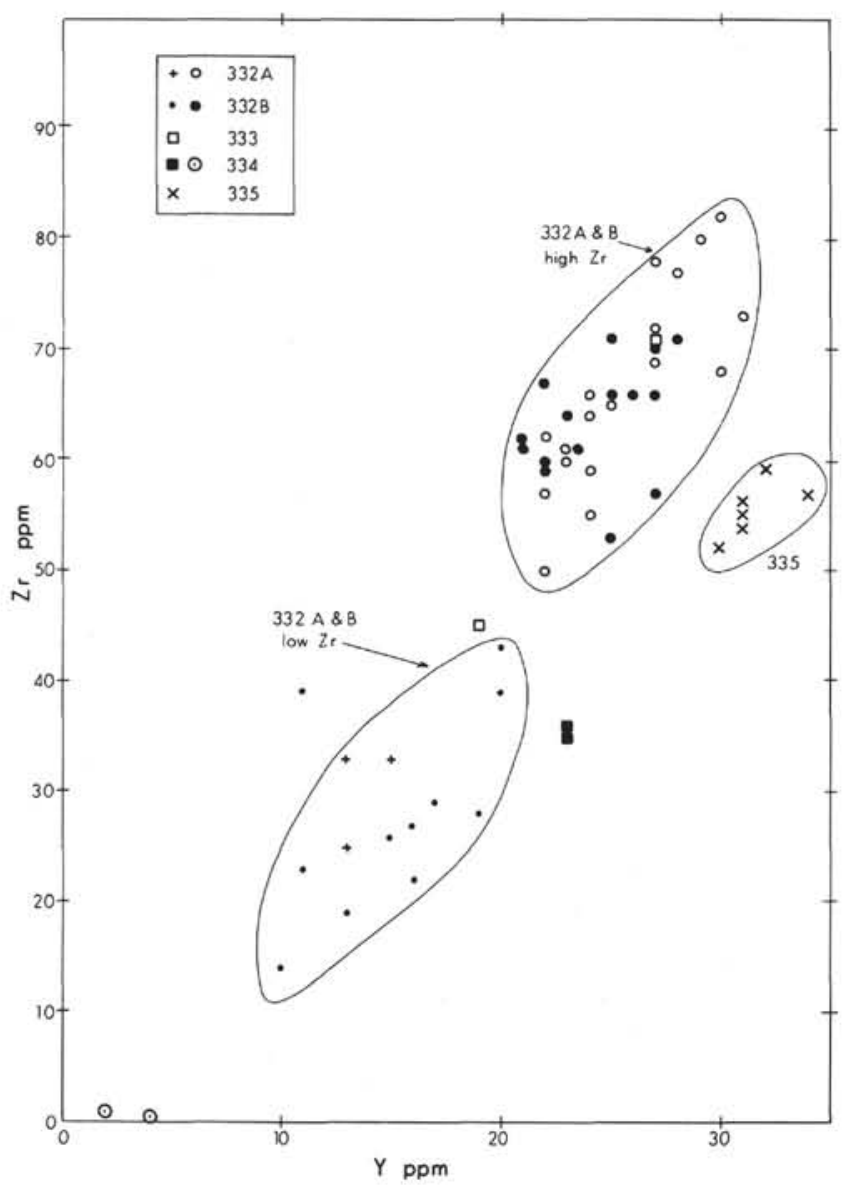

Figure 1. $\mathrm{Zr}$ and $Y$ in Leg 37 igneous rocks.

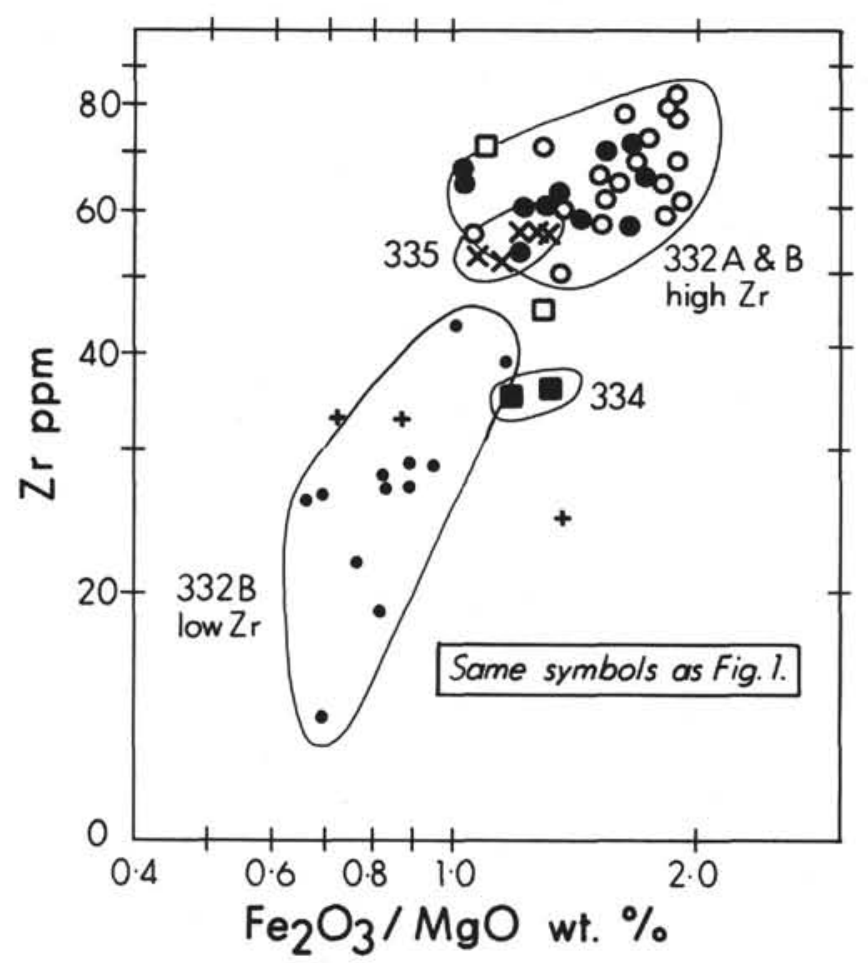

Figure 2. $\mathrm{Zr}$ and $\mathrm{Fe}_{2} \mathrm{O}_{3} * / \mathrm{MgO}$ in Leg 37 igneous rocks.

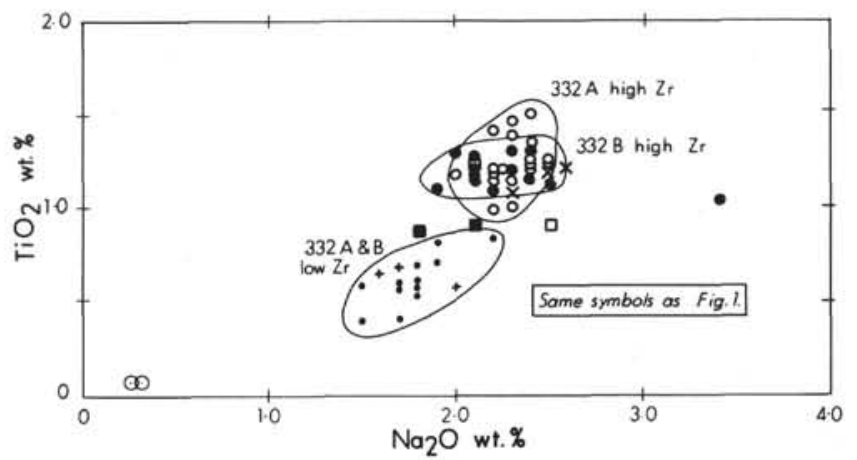

Figure 3. $\mathrm{TiO}_{2}$ and $\mathrm{Na}_{2} \mathrm{O}$ in Leg 37 igneous rocks.

$\mathrm{Fe}_{2} \mathrm{O}_{3} / \mathrm{MgO}$, indicating possible olivine control of these rock compositions.

Figures 6 and 7 show the high degree of linear correlation between $\mathrm{Y}, \mathrm{Nb}$, and $\mathrm{Zn}$, with $\mathrm{Zn}=3.2 \mathrm{Y}$ and $\mathrm{Y}$ $=1.5 \mathrm{Nb}+10$ except at Site 335 . The latter may indicate occurrence of $\mathrm{Nb}$ only in subsidiary phases in these basalts, the $10 \mathrm{ppm} Y$ being the average component of $\mathrm{Y}$ in the principal silicate phases. The $\mathrm{Zn}-\mathrm{Y}$ correlation raises new problems, however.

\section{ZN, CO, AND NI IN LEG 37 IGNEOUS ROCKS}

The problem of $\mathrm{Zn}$ is examined further in Figure 8 and $\mathrm{Co}$ and $\mathrm{Ni}$ are illustrated in Figure 9. Using $\mathrm{Y}$ as a key element, $\mathrm{Ni} / \mathrm{Y}$ and $\mathrm{Zn} / \mathrm{Y}$ ratios show systematic behavior. Using the shipboard classification, it can be seen that units $332 \mathrm{~A}-1$ and $332 \mathrm{~B}-1$ have similar ratios as do units 332A-1 and 332B-7. Ni is high in all low- $\mathrm{Zr}$ units (332A-1 and 7, 332B-1, -4, -5, -7, and -8) also in 332B-9 and -11. Further, Unit 3 of 332A and Unit 10 of 332B both appear to be divisible into two distinct subunits. Variations of Ni probably reflect olivine control, whereas $\mathrm{Zn}$ variations are due to all ferromagnesian minerals and magnetite. Both Holes 332A and 332B therefore penetrated lava piles of widely varying origin, most clearly shown by trace elements and to a lesser extent by $\mathrm{Fe}_{2} \mathrm{O}_{3} / \mathrm{MgO}$ and $\mathrm{Na}_{2} \mathrm{O}$.

Co, however, shows no systematic variation as seen in Figure 9. Ni/Co varies widely and comparatively randomly from 10 to 1 . With the information on hand, no cause for this variation has been found.

\section{STRONTIUM IN LEG 37 IGNEOUS ROCKS}

Like the elements discussed previously, $\mathrm{Sr}$ shows a clear pattern vis-a-vis $\mathrm{Zr}$, but with some overlap between the various groups. When $\mathrm{Sr}$ is examined against $\mathrm{K}_{2} \mathrm{O}$ (Figure 10), it is seen that $\mathrm{K} / \mathrm{Sr}$ varies widely in these rocks, averaging 20 in the high- $\mathrm{Zr}$ groups, 15 in the low-Zr groups, and 25 at Sites 334 and 335. The low $\mathrm{K} / \mathrm{Sr}$ in the low- $\mathrm{Zr}$ group is consistent with the notion that this group has been formed by a high degree of partial melting with limited subsequent fractional crystallization. There are no observable correlations of $\mathrm{Sr}^{87} / \mathrm{Sr}^{86}$ (Gray et al., this volume) with $\mathrm{Sr}$, explicable on groups of isotope exchange with seawater rather than element exchange. 


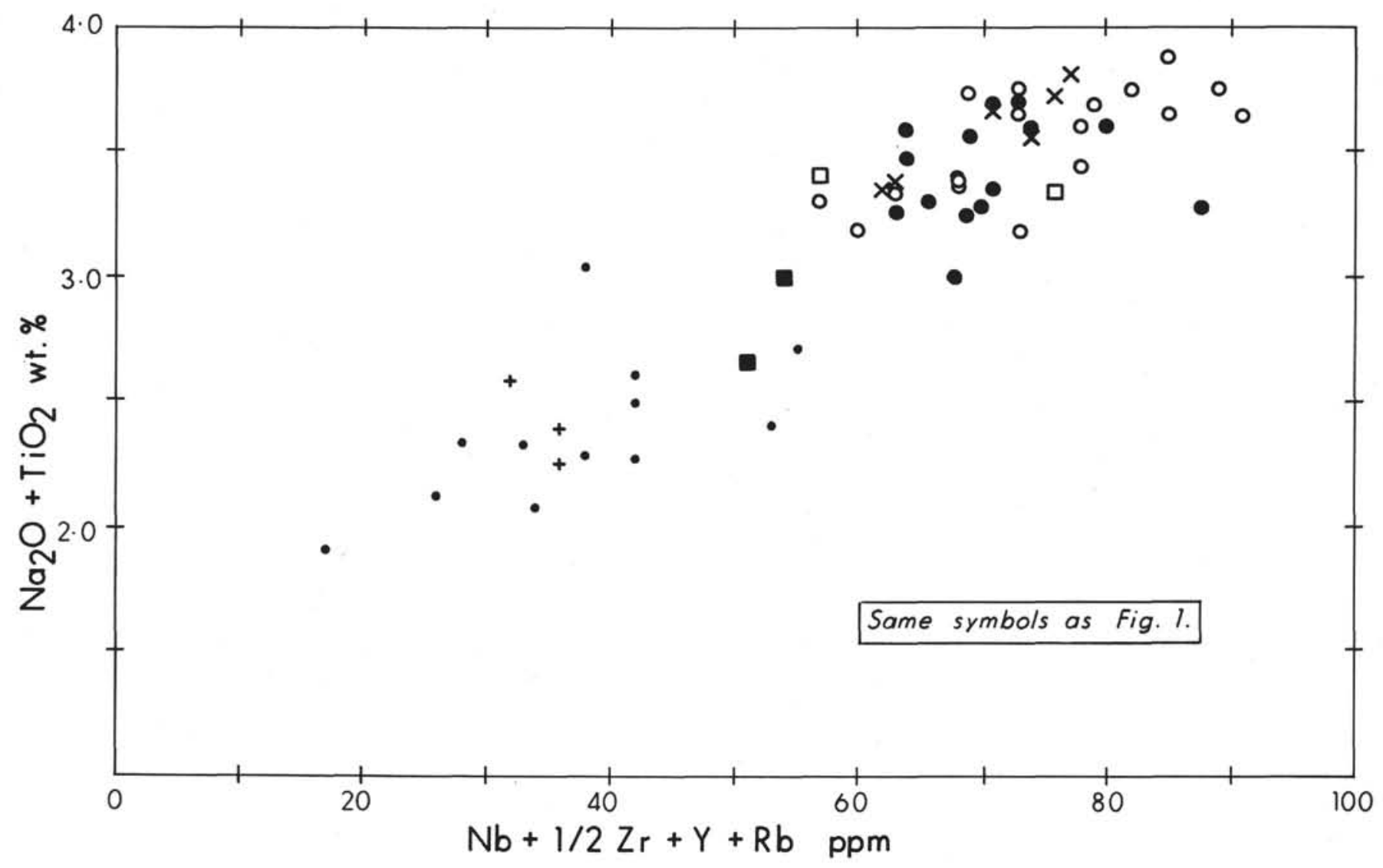

Figure 4. $\mathrm{Na}_{2} \mathrm{O}+\mathrm{TiO}_{2}$ and $\mathrm{Nb}+1 / 2 \mathrm{Zr}+\mathrm{Y}+\mathrm{Rb}$ in Leg 37 igneous rocks.

\section{DISCUSSION}

In their discussion of the origin of basalts recovered from Leg 6, Ridley et al., (1974) quote various geochemical parameters which are believed to reflect alteration processes, and other parameters were discussed by Cann (1970). Besides $\mathrm{Ti}, \mathrm{Zr}, \mathrm{Y}$, and $\mathrm{Nb}$, which are thought to remain constant during alteration, $\mathrm{MgO}, \mathrm{CaO}$, and $\mathrm{Sr}$ are cited as decreasing during alteration, and $\mathrm{K}$ and $\mathrm{Rb}$ are cited as increasing. On the basis of the above results, we consider that there is little direct geochemical evidence for alteration of element abundances in these basalts, even though the oxygen and strontium isotopes do show conclusive evidence of exchange. If alteration is responsible for the proposed division into low- and high- $\mathrm{Zr}$ types, it must have operated in such a way as to produce very low abundances of the supposedly inert elements and at the same time change $\mathrm{Fe}_{2} \mathrm{O}_{3} / \mathrm{MgO}$ and $\mathrm{Na}_{2} \mathrm{O}$ without significant alteration of the major minerals in these rocks.Unfortunately, at the time of writing, only four thin sections of the low- $\mathrm{Zr}$ basalts are available to us; of these $332 \mathrm{~A}$ $40-3,37-39 \mathrm{~cm}$ (\#4B) is a comparatively fresh almost holocrystalline basalt with abundant plagioclase and augite microphenocrysts, 332B-2-5, 103-106 cm (\#10) is broadly similar in appearance, and has only some $5 \%$ altered brownish glassy residuum, and 332B-21-1, 27-30 $\mathrm{cm}(\# 1 \mathrm{~B})$ is a very fine grained quench-textured basalt with very little visible alteration. These three are not particularly distinguishable in their general appearance in thin section from the score of sections available from high-Zr types. However, 332B-35-2, 105-108 cm (\#1N) is moderately altered and its geochemistry could have been significantly affected by this process. It has the highest $\mathrm{Sr}^{87} / \mathrm{Sr}^{86}$ and $\delta \mathrm{O}^{18}$ of all the samples so far measured.

It is therefore concluded that the major cause of the variations in the geochemistry of these rocks lies in their melting history rather than secondary or highlevel alteration processes. The isotopic anomalies must therefore be due to exchange rather than mineralogical reaction processes. It is also concluded that $332 \mathrm{~A}$, Unit 3 and 332B, Unit 10 should each be subdivided. Finally, the low-Zr types (Units 1 and 7 of $332 \mathrm{~A}$ and Units 1,4 , 5 ?, 7,8 , and 10A of 332B) are very deficient indeed in $\mathrm{Nb}, \mathrm{Zr}, \mathrm{Y}, \mathrm{Sr}, \mathrm{Rb}, \mathrm{P}_{2} \mathrm{O}_{3}, \mathrm{TiO}_{2}$, and $\mathrm{Na}_{2} \mathrm{O}$, even for basalts, and must have originated under rather extreme conditions, presumably very high degrees of partial melting of the upper mantle.

\section{TECHNIQUES}

All analyses were made on a Philips 1212 XRF unit using neat powdered briquettes, prepared directly from powders as supplied by Dalhousie University (those samples with $\mathrm{Ba}$ and $\mathrm{Co}$ ) or as crushed at Edmonton in a tungsten carbide swing-mill. Matrix corrections were carried out by an iterative computer procedure, and the standards used were the current international standards for major elements and spiked glasses specially 


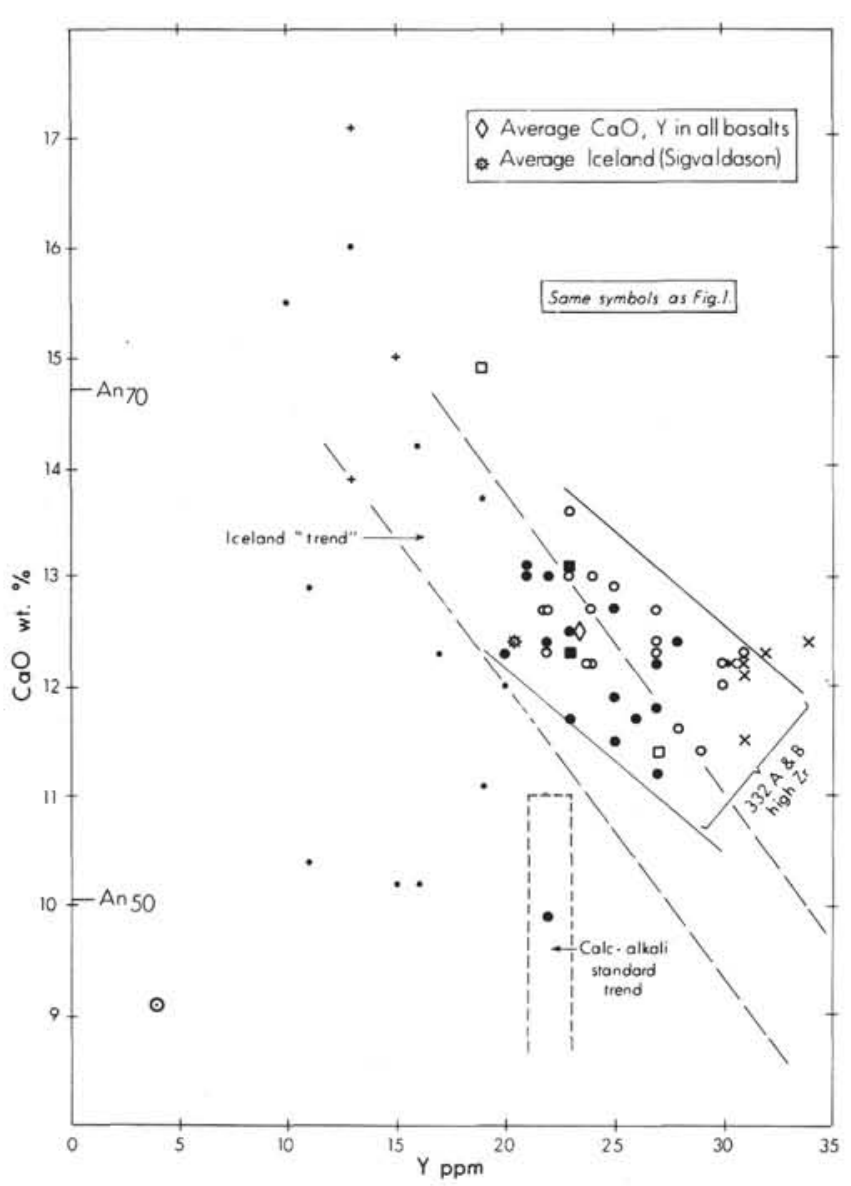

Figure 5. $\mathrm{CaO}$ and $\mathrm{Y}$ in Leg 37 igneous rocks with the Icelandic pattern for comparison.

prepared by Pilkington Glass for the trace elements (Brown et al., 1970, p. 212-213).

\section{ACKNOWLEDGMENTS}

We wish to acknowledge discussions with colleagues at the University of Alberta on the subject matter of this report and financial assistance from the Natural Environment Research Council of Great Britain for support of the X-ray fluorescence laboratory at the University of Durham.

\section{REFERENCES}

Brown, G.M., Emeleus, C.H., Holland, J.G., and Phillips, R., 1970. Mineralogical, chemical and petrological features of

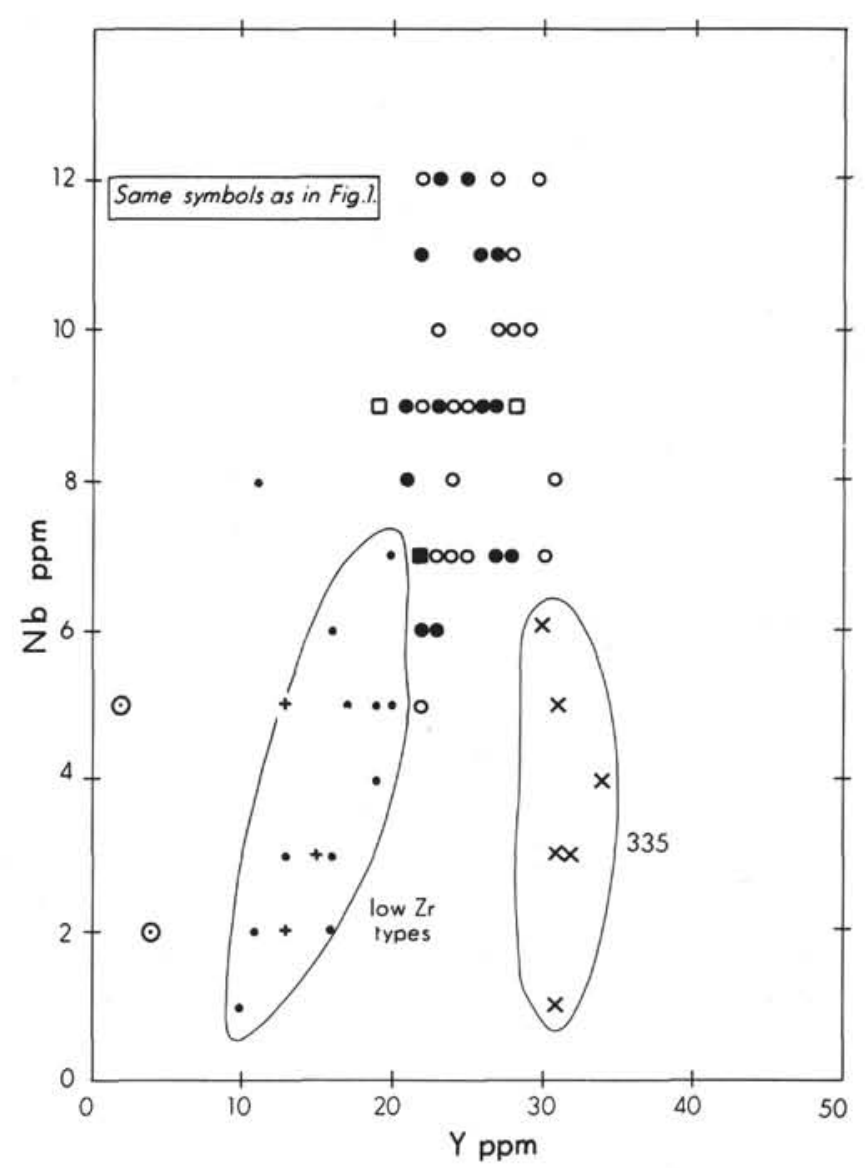

Figure 6. $\mathrm{Nb}$ and $\mathrm{Y}$ in Leg 37 igneous rocks.

Apollo 11 rocks and their relationship to igneous processes. In Levinson, A.L. (Ed.), Apollo 11 Lunar Sci. Conf. Proc.: New York (Pergamon Press), v. 1, p. 195219.

Cann, J.R., 1970. Rb, Sr, Y, Zr and $\mathrm{Nb}$ in some ocean floor basaltic rocks: Earth Planet. Sci. Lett., v. 10, p. 7-11.

Lambert, R. St J. and Holland, J.G., 1974. Yttrium geochemistry applied to petrogenesis utilizing calciumyttrium relationships in minerals and rocks: Geochim. Cosmochim. Acta, v. 38, p. 1393-1414.

Ridley, W.I., Rhodes, J.M., Reid, A.M., Jakes, P., Shih, C., and Bass, M.N. 1974. Basalts from Leg 6 of the Deep-Sea Drilling Project: J. Petrol., v. 15, p. 140-159.

Sigvaldason, G.E., 1974. Basalts from the centre of the assumed Icelandic mantle plume: J. Petrol., v. 15, p. 497 524. 


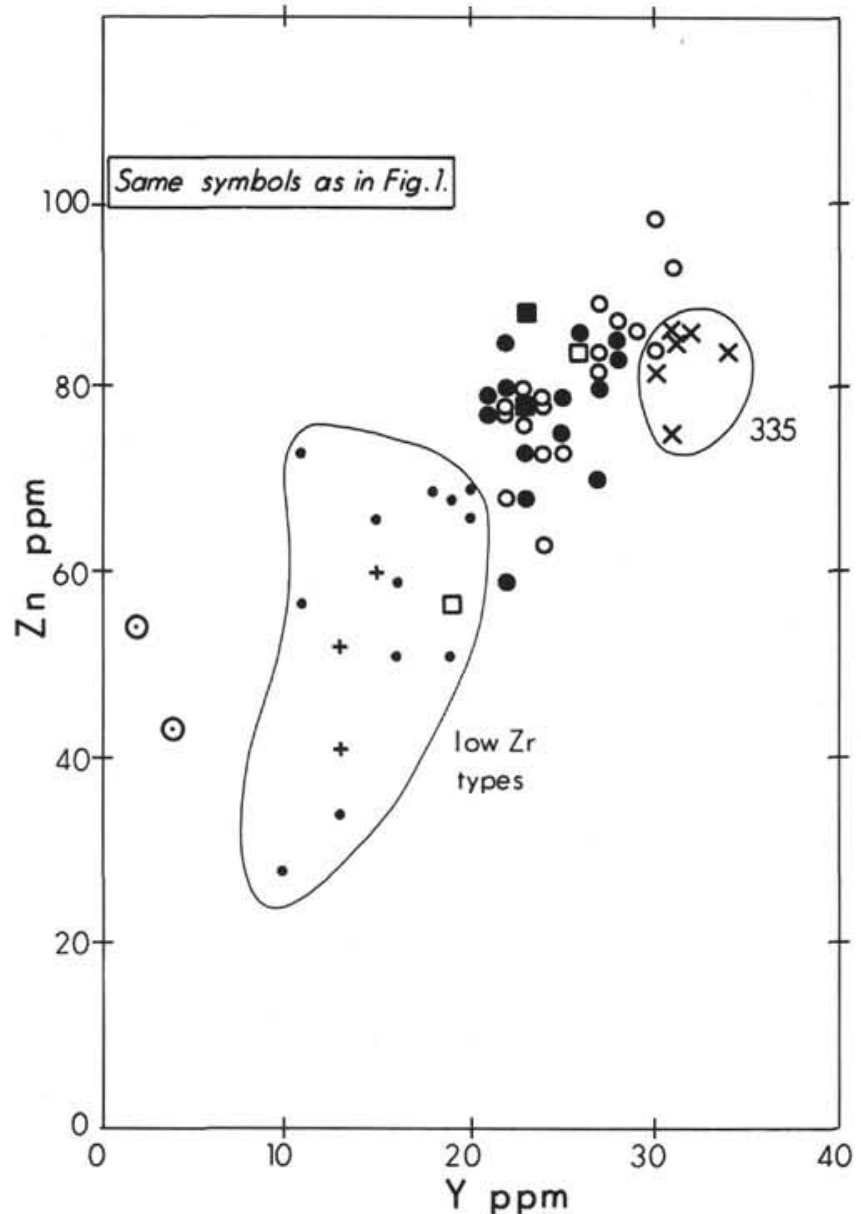

Figure 7. Zn and $Y$ in Leg 37 igneous rocks.

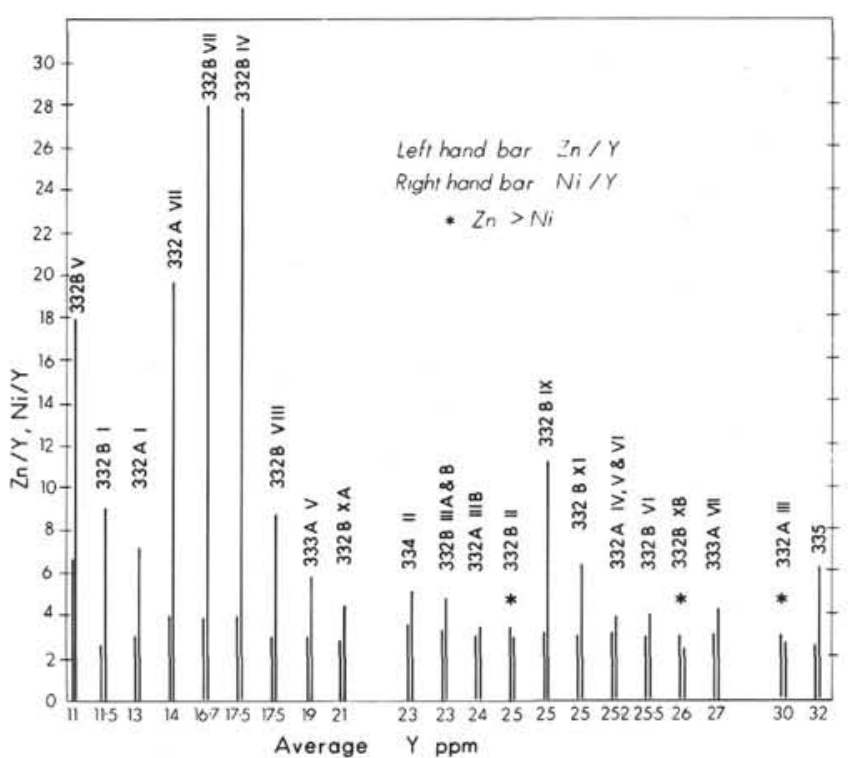

Figure 8. Ni, Zn, and $Y$ in Leg 37 igneous rocks. 


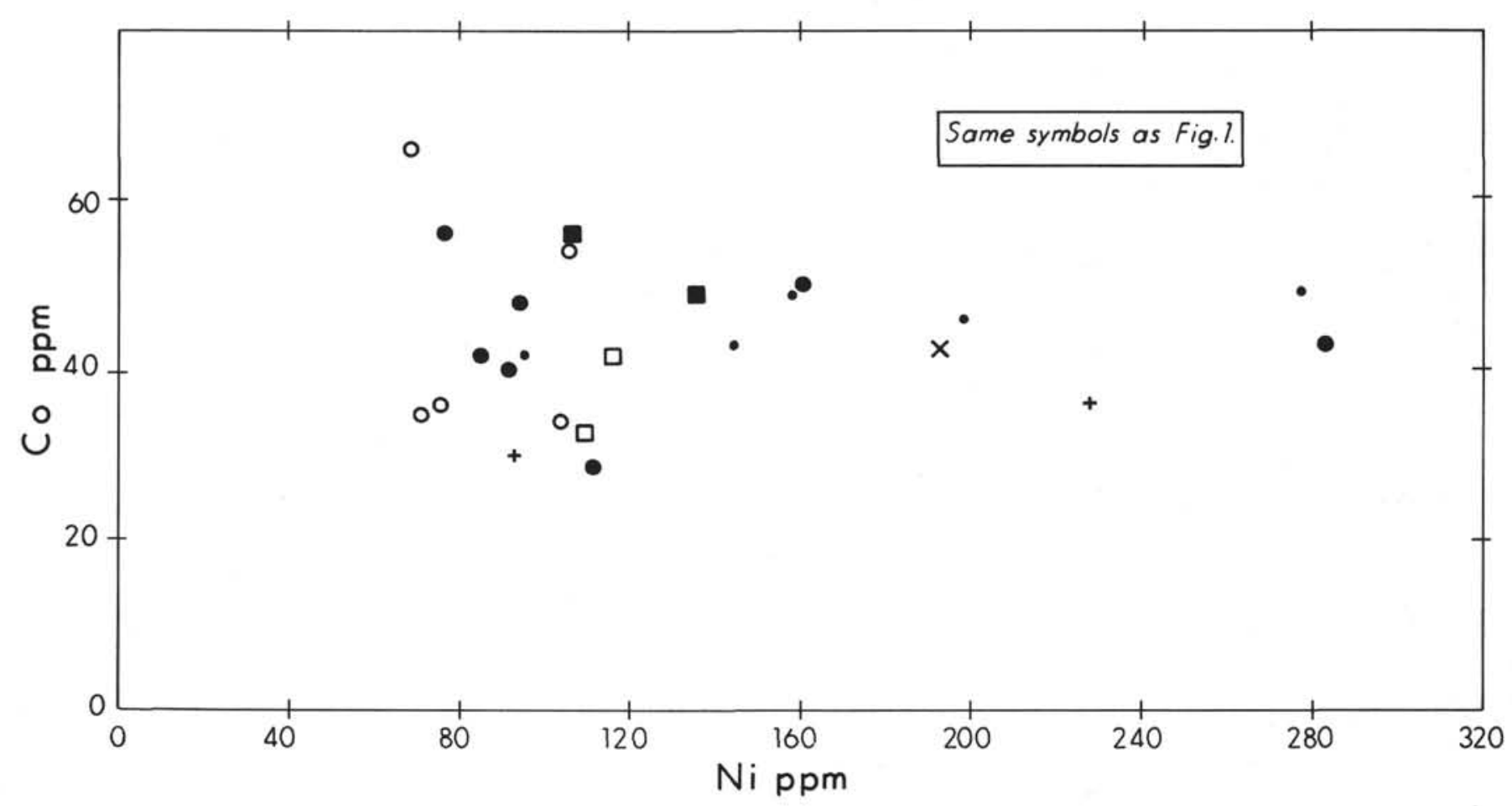

Figure 9. Co and Ni in Leg 37 igneous rocks.

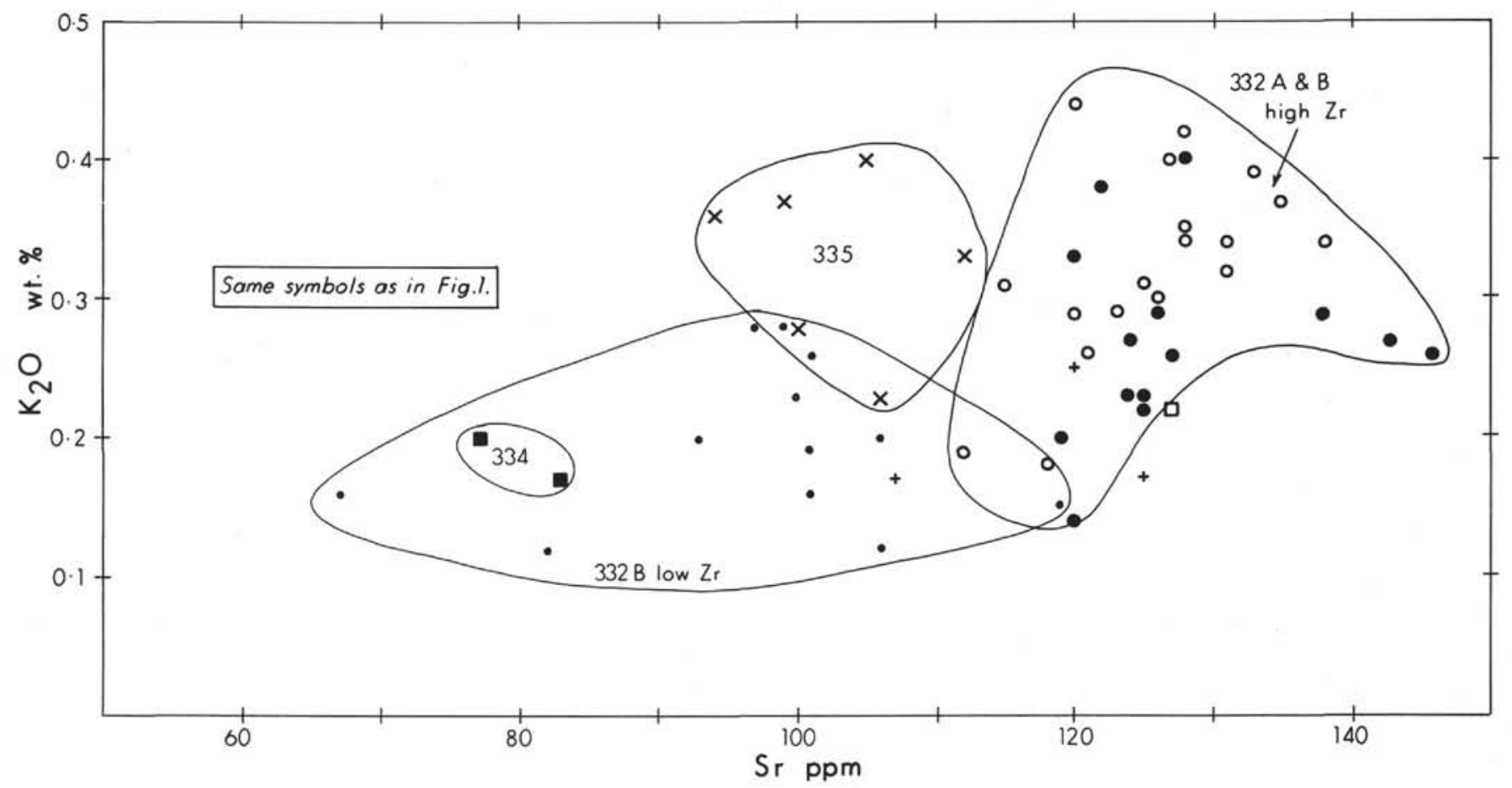

Figure 10. $\mathrm{K}_{2} \mathrm{O}$ and $\mathrm{Sr}$ in Leg 37 igneous rocks. 